\title{
Breeding management of mares in late reproductive age considering improvement of welfare. A review
}

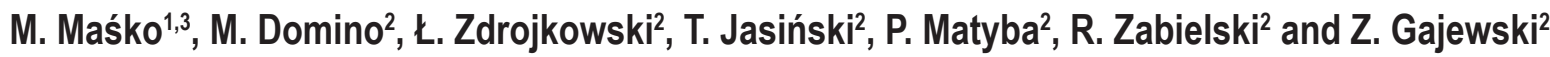 \\ Warsaw University of Life Sciences (WULS) - SGGW \\ Nowoursynowska 100, 02-797 Warsaw, Poland \\ ${ }^{1}$ Faculty of Animal Science, Department of Animal Breeding \\ ${ }^{2}$ Faculty of Veterinary Medicine, Department of Large Animal Diseases with Clinic, \\ Veterinary Research Centre and Centre for Biomedical Research
}

KEY WORDS: reproduction, breeding, fertility, age, mares

Received: $\quad 10$ April 2018

Revised: $\quad 20$ July 2018

Accepted: 11 December 2018

${ }^{3}$ Corresponding author:

e-mail: malgorzata.masko@gmail.com
ABSTRACT. It is thought that mares being 20 years old can still give birth to foals, some individuals are even longer capable to be pregnant. However, each year mare owners should realize that the older mare the more decreased horse fertility. An aged mare that has recently had a foal has a greater chance to become pregnant again than a mare of similar age that has remained barren despite being bred over multiple oestrous cycles during the previous breeding season. The fact that an older mare has never been mated previously (maiden mare) does not indicate whether she will be fertile or not. Older mares may develop clinical problems that may adversely affect fertility, which leads to consecutive stressful and troubling interventions of breeders and veterinarians. So, strategies increasing the probability of pregnancy in horses are essential for breeding management and for sure will help to maintain animal welfare at high level.

\section{Introduction}

Mares retain the ability to produce offspring for a relatively long period of time. The average horse lifespan is $25-30$ years and it is estimated that mare can give birth to a healthy foal till the age of 20 years, or even later. Nevertheless, fertility in older mares decreases significantly every year and so the possibility of obtaining offspring is an individual feature (Scoggin, 2015). When comparing two mares with different reproductive statuses at the same age (over 15 years old) it is estimated that mare which foaled in the previous breeding season will have a greater chance to get pregnant than mare with fertilization or gestation problems. It cannot be assumed that mare which has never given birth will be fertile at an older age (Bosh et al., 2009). Therefore, breeding management of older mares is difficult and requires investment of time, money, and a lot of effort (Byszewski and Gromnicka, 1994).

\section{The breeding aspect of older mares reproduction}

Horses are late maturing animals with the lowest reproduction ratio among farm animals. In the population of broodmares about $5 \%$ is not mated due to the lack of heat, $23 \%$ do not get pregnant despite many attempts, and in almost $10 \%$ of mares the pregnancy is lost at different stages. Including loss of foals at peripartum period, the overall 
outcome at the end of breeding season can be lower than estimated (Marteniuk et al., 1998). What is more, a big emphasis is put on selecting traits of successful sport and working horses, without paying attention to reproductive features. This often leads to the improvement of race and sport skills and reproductive parameters deterioration at the same time (Byszewski and Gromnicka, 1994). As a result, breeders are seeking animals that not only would achieve excellent sport and race results but also would get considerable number of offspring which inherit desirable traits. This is the reason for using genetically valuable broodmares as long as possible. As a consequence the best mares are used for breeding until gaining a relatively old age, which may cause a problem of decreased fertility in this group (Nowicka-Posluszna and Zygmunt, 2001).

Reproduction of mares used in sports may be problematic. It is proved that horses which race often have lower fertility or proper embryo development is disturbed. Frequent body temperature changes and exposure to stress result in hormonal balance perturbations. What is more, sport horse owners in many cases decide to use hormonal treatment to block normal oestrus cycle. Because of the unusual levels of progestins in blood, physiological levels are often achieved after a long time. Also drugs used in racing horses often affect horse fertility. Vaccinations against gonadotropin releasing hormone $(\mathrm{GnRH})$, used for suppression of oestrus, eliminate mares from breeding for many weeks (Elhay et al., 2007). Also, it is impossible for recently foaled mare to start racing again immediately, which is connected with huge stress associated with separation from foal, as well as with somatic changes in mare's musculature and racing outcome (Stout and Colenbrander, 2004; Burger et al., 2008; Sairanen et al., 2011).

Warmblood mares achieve sexual maturity at the age of 16-17 months and the full reproductive maturity at the age of 4-5 years, which is the optimal time for the first attempt to reproduce. Getting pregnant too early, at the age of 2.5 years, delays or can even stop further somatic development (Samper, 2009). Breeding strategies include selection of young mares which have just matured as well as older mares which have already completed sports career. Broodmare can give offspring every year and the peak of fertility is achieved at the age of 6-7 years (Wilsher and Allen, 2003; McKinnon et al., 2011). Around the age of 15 years mares fertility decreases gradually and affects reproduction ratio in an unfavourable manner (elongation of service period and average period between parturitions) (Davies Morel and O'Sullivan,
2001; Ishii et al., 2001; Nowicka-Posluszna and Zygmunt, 2001). Thus, this can be considered as a consequence of aging of the reproductive system. The definitions of particular indicators, their values and the changes with age are shown in Table 1.

The pregnancy ratio in young fertile mares is $50-60 \%$ if mare is bred to one fertile stallion in one heat, whereas in older mares the same ratio is $30-40 \%$. What is more, older mares usually require more oestrus cycles to get pregnant than younger ones (Bos and Van der Mey, 1980; Camillo et al., 1997; Davies Morel et al., 2005).

\section{Clinical aspect of older mares' reproduction}

Breeding season of an older mare should be preceded by a thorough clinical examination. Anamnesis should include reproduction history. If older mare (over 15 years old) does not show any signs of infertility, clinical, ultrasonographic examinations and endometrial swab samples taken for bacteriological investigations will be sufficient. If unsuccessful attempts have been performed to fertilize the mare, the examination should additionally include:

- detailed evaluation of perineal anatomy (measurement of the angle and muscle tonus of the vulva),

- examination with speculum,

- manual palpation of cervix,

- detailed ultrasonographic evaluation of reproductive system,

- endometrial sample collection for bacteriology and cytology,

- uterine mucous membrane biopsy (Bracher et al., 1997; Samper and Pycock, 2007).

In clinical examination, one or more causes of decreasing fertility in older mares can be found. The changes in older mares include:

- anatomical abnormalities in vulva,

- increased susceptibility to uterus inflammation,

- persistent post breeding endometritis,

- progressive uterine fibrosis,

- endometrial cyst formation,

- increased incidence of ovulation failure (Carnevale et al., 1993; Wilsher and Allen, 2003; Davies Morel et al., 2005).

Progressive cranial collapse of dorsal labia commissure becomes more significant with the age because of gradual atrophy of perianal fat and decreased mass and tonus of surrounding skeletal muscles. Therefore, taking into consideration older mares 


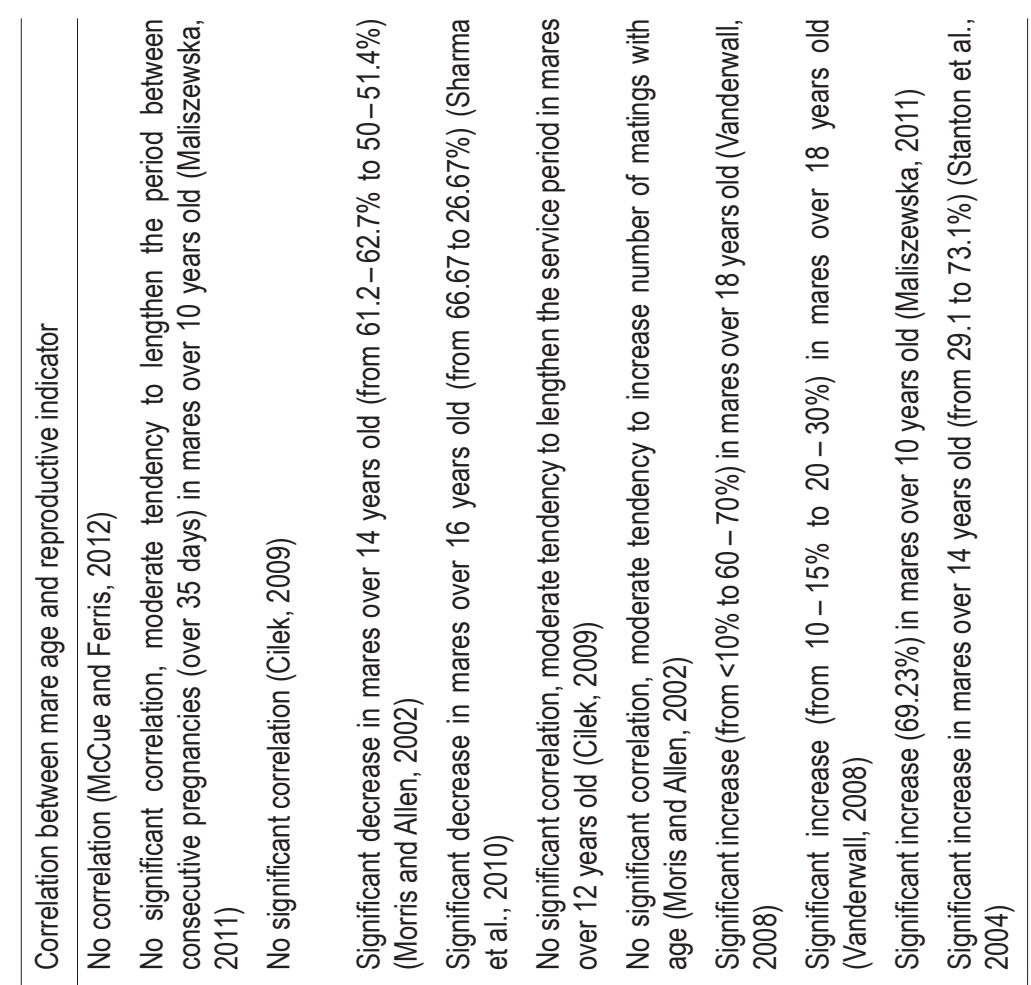


in poor condition, the anatomical abnormalities are particularly aggravated. Changes in angulation of vulva may significantly limit the possibility to obtain and maintain pregnancy. Deformed labia can no longer act as a mechanical barrier for ascending infections of reproductive system and can allow air aspiration into the vagina (pneumovagina). Anatomical abnormalities are an indication to perform Caslick's surgery to decrease the size of vaginal opening and therefore limit the risk of air aspiration and infections (Wilsher and Allen, 2003; McKinnon et al., 2011).

As the mare gets older, some functional and anatomical changes in endometrium might occur, including: endometrial fibrosis, inflammatory cell infiltration, endometrial cyst development and uterine gland atrophy. Degenerative changes of endometrium, classified as endometriosis develop regardless of the number of pregnancies in mares which have not given birth as well as in multiparous ones (Pycock, 2006). Diagnosis, fertility prognosis and estimation of further ability to complete pregnancy is based on endometrium biopsy results. In the four-grade scale system the $1^{\text {st }}$ category includes healthy mares with no pathological changes in endometrium, whereas other categories describe degenerative changes: mild ( $2^{\text {nd }} \mathrm{A}$ and $\mathrm{B}$ categories) to severe ( $3^{\text {rd }}$ category). The more advanced changes in endometrium worsen the prognosis for fertilization, which is for the category I: 80-90\%, IIa: 50-80\%, IIb: 10-50\%, III: 10\% (Samper and Pycock, 2007; Hoffmann et al., 2009).

Old mares are more susceptible to infections and post breeding endometritis. Decreased uterine contractility results in impaired expulsion of seminal plasma, sperm cells, cellular elements and inflammatory exudate after mating or inseminating. This can lead to pathological fluid accumulation in the uterus. The change in uterine environment makes it impossible for the migrating embryo to develop and may cause early embryonic death (Carnevale et al., 1993; Bracher et al., 1997).

In middle-aged mares an increased number of incidences of early embryonic death is observed. Chronic endometritis, post breeding endometritis and luteal insufficiency start playing a significant role. Comparing plasma progesterone levels in old and young mares which are in diestrus and early pregnancy (28 days after fertilization), significantly higher plasma progesterone concentration in older mares is observed. It is suspected that older mares require higher progesterone concentration for the maintenance of pregnancy (Hendriks et al., 2009). The incidence of early embryonic death (until day 16 after fertilization) is estimated at $9 \%$ in young mares and at $62-73 \%$ in old mares. In the latter group, days 5 and 6 after fertilization are critical as a sudden increase of embryonic death incidence is observed. Late embryonic death (between days 16 and 40 of pregnancy) occurrence is estimated at $5-24 \%$ in young mares, whereas in old mares the percentage is much higher (Ball, 1988; Meyers et al., 1991).

Furthermore, old mares (over 15 years old) can demonstrate limited reproductive performance because of functional changes in ovaries (Madil, 2002). The first ovulation in the season may occur with two weeks delay (Van Niekerk and Van Heeden, 1972), and the period between two consecutive ovulations can be extended due to longer follicular phase (Carnevale et al., 1993; Wilsher and Allen, 2003). Repeating extended follicular phase (no ovarian response to high GnRH blood concentration) and more frequent ovulation disorders might suggest that the mares reproductive system is aging, which results in the small amount of primordial ovarian follicles (Montovan et al., 1990; Carnevale et al., 1993). There is a higher incidence of spontaneous ovulation disorders (McCue and Squires, 2002) and a decreased response to treatment inducing ovulation in older mares (Farquhar et al., 2000). The number of anovulatory hemorrhagic follicles (AHF) increases with the age and is found in about $4.5 \%$ of mares at the age of 10 years old and in more than 13\% of mares older than 16 years (McCue and Squires, 2002).

Moreover, as the mare gets older, the risk of Cushing syndrome increases and this can additionally contribute to lower reproductive performance (Magee et al., 2009). Equine Cushing Disease (ECD) usually occurs in old horses (over 20 years old), as a consequence of losing the hypothalamic dopaminergic inhibition, which can promote hypertrophy, hyperplasia of pituitary gland or oncogenic transformation into pituitary adenoma. The clinical signs of ECD include excessive hair growth, loosing hair, polyuria, polydipsia, diaphoresis (McCue, 2002) as well as reproductive disorders manifesting in disrupted heat behaviour and decreased fertility (Dybdal et al., 1994).

\section{Welfare aspect in horse breeding}

In the wild, horses can constantly interact with each other. Nowadays neither natural mating nor artificial insemination allow to express normal behaviour (McDonnell, 2000). Because of time limitations animals interact with each other very rarely, 
which is not proper for them. Hobble may be sometimes used in mares during coitus to prevent harming stallion. Furthermore, each mating relates to transportation of horses, even over long distances (Mills, 2013; Campbell and Sandøe, 2015). Artificial insemination (AI) eliminates this inconvenience, however it is not allowed in Thoroughbred horses breeding.

If fertility is lowered, profound examination should be performed, even if it leads to discomfort of mares. It is helpful in evaluation of breeding capability and allows to choose the best treatment, saving animals from needless efforts. Many troubling (uterine lavage) or painful (surgeries) operations may be omitted, if results of properly performed examinations demonstrate its redundancy (Ashley et al., 2005; Robertson and Sanchez, 2010).

Because of fertility problems in older mares, breeding management should be focused on limitation of negative welfare effects. By reducing the number of fertilization attempts breeding management is limiting many kinds of stressful situations, both for mares and stallions (Campbell and Sandøe, 2015). Lowered number of transportations, inseminations or matings and other actions can be also expected. Estimation of chances to get a foal helps owners to make decisions if fertilize mare or not.

\section{Breeding management of older mares}

Due to decreased number of complete oestrus cycles and increased incidence of uterine pathologies in older mares, it is necessary to put considerable effort into mating and insemination strategies. Breeding management of old mares aims at increasing possibility to obtain offspring and includes:

- correcting anatomical abnormalities of vulva (Caslick's surgery),

- using very good quality semen (highly fertile stallion) (Wilsher and Allen, 2003),

- choosing the optimal time of AI/mating (frequent ultrasonographic examination),

- pharmacological stimulation of ovulation for precise prediction of ovulation time (human chorionic gonadotropin (hCG) or GnRH agonist) (Farquhar et al., 2000; McKinnon et al., 2011),

- single insemination possibly closest to the moment of ovulation,

- confirming ovulation with ultrasonographic examination,

- post breeding monitoring of fluid accumulation in uterus,
- uterine lavage in case of fluid accumulation and uterine contractility stimulation (oxytocin) - every day for 4 days after insemination, starting $6 \mathrm{~h}$ after insemination,

- supporting early pregnancy development with progesterone supplementation from day 5 to 120 after ovulation (altrenogest) (Carnevale et al., 1993; Bracher et al., 1997; Davies Morel et al., 2005).

\section{Conclusions}

It is difficult to get offspring from old mares previously used in sport, because the use of this horses is extremely specific and they are not selected into breeding features. Older mares tend to drop fertility indexes, not only because of insemination problems, but also because of frequent pregnancy losses. Moreover, some individuals are not capable to get pregnant anymore. It is crucial to perform appropriate examinations to determine exact degenerative changes and afterwards to apply medical treatment helping mares to get pregnant. During operations conducted in breeding management of older mares welfare should be taken into consideration. Proper handling may be useful in improvement of mare's welfare during breeding.

\section{References}

Ashley F.H., Waterman-Pearson A.E., Whay H.R., 2005. Behavioural assessment of pain in horses and donkeys: application to clinical practice and future studies. Equine Vet. J. 37, 565-575, https://doi.org/10.2746/042516405775314826

Ball B.A., 1988. Embryonic loss in mares. Incidence, possible causes, and diagnostic considerations. Vet. Clin. North Am. Equine Pract. 4, 263-290, https://doi.org/10.1016/S0749-0739(17)30641-7

Bos H., Van der Mey G.J.W., 1980. Length of gestation periods of horses and ponies belonging to different breeds. Livest. Prod. Sci. 7, 181-187, https://doi.org/10.1016/0301-6226(80)90105-0

Bosh K.A., Powell D., Shelton B., Zent W., 2009. Reproductive performance measures among Thoroughbred mares in central Kentucky, during the 2004 mating season. Equine Vet. J. 41, 883-888, https://doi.org/10.2746/042516409X456068

Bracher V., Gestenberg C., Allen W.R., 1997. The influence of endometrosis on fertility, placentation and fetal development in the horse. Pferdeheilkunde 13, 465-473, https://doi. org/10.21836/PEM19970507

Burger D., Wohlfender F., Imboden I., 2008. Managing a mare for breeding and sport. Pferdeheilkunde 24, 102-107, https://doi. org/10.21836/PEM20080122

Byszewski W. Gromnicka E., 1994. Results of reproduction of mares in the state-horse stud farms in 1983-1992 (in Polish). Med. Wet. 50, 493-495

Camillo F., Marmorini P., Romagnoli S., Vannozzi I., Bagliacca M., 1997. Fertility at first post partum estrous compared with fertility at the following estrous cycles in foaling mares and with fertility in nonfoaling mares. J. Equine Vet. Sci. 17, 612-616, https://doi. org/10.1016/S0737-0806(97)80189-X 
Campbell M.L.H., Sandøe P., 2015. Welfare in horse breeding. Vet. Rec. 176, 436-440, https://doi.org/10.1136/vr.102814

Carnevale E.M., Bergfelt D.R., Ginther O.J., 1993. Aging effect on follicular activity and concentrations of $\mathrm{FSH}$, LH and progesterone in mare. Anim. Reprod. Sci. 31, 287-299, https://doi.org/10.1016/0378-4320(93)90013-H

Cilek S. 2009. The survey of reproductive success in Arabian horse breeding from 1976-2007 at Anadolu State farm in Turkey. J. Anim. Vet. Adv. 8, 389-396

Davies Morel M.C.G., Newcombe J.R., Swindlehurst J.C., 2005. The effect of age on multiple ovulation rates, multiple pregnancy rates and embryonic vesicle diameter in the mare. Theriogenology 63, 2482-2493, https://doi.org/10.1016/j. theriogenology.2004.09.058

Davies Morel M.C.G., O'Sullivan J.A.M., 2001. Ovulation rate and distribution in the thoroughbred mare, as determined by ultrasonic scanning: the effect of age. Anim. Reprod. Sci. 66, 59-70, https://doi.org/10.1016/S0378-4320(01)00092-6

Dybdal N.O., Hargreaves K.H., Madigan J.E., Gribble D.H., Kennedy P.C., Stabenfeldt G.H., 1994. Diagnostic testing for pituitary pars intermedia dysfunction in horses. J. Am. Vet. Med. Assoc. 204, 627-632

Elhay M., Newbold A., Britton A., Turley P., Dowsett K., Walker J., 2007. Suppression of behavioural and physiological oestrus in the mare by vaccination against $\mathrm{GnRH}$. Aust. Vet. J. 85 , 39-45, https://doi.org/10.1111/j.1751-0813.2006.00092.x

Farquhar V.J., McCue P.M., Vanderwall D.K., Squires E.L., 2000. Efficiency of the $\mathrm{GnRH}$ agonist deslorelin acetate for inducing ovulation in mares relative to age of mare and season. $\mathrm{J}$. Equine Vet. Sci. 20, 722-725, https://doi.org/10.1016/S07370806(00)80183-5

Hendriks W.K., Colenbrander B., van der Weijden G.C., Stout T.A.E., 2009. Maternal age and parity influence ultrasonographic measurements of fetal growth in Dutch Warmblood mares. Anim. Reprod. Sci. 115, 110-123, https://doi.org/10.1016/j. anireprosci.2008.12.014

Hoffmann C., Ellenberger C., Mattos R.C., Aupperle H., Dhein S., Steif B., Schoon H.-A., 2009. The equine endometrosis: new insights into the pathogenesis. Anim. Reprod. Sci. 111, 261278, https://doi.org/10.1016/j.anireprosci.2008.03.019

Ishii M., Shimamura T., Utsumi A., Jitsukawa T., Endo M., Fakuda T., Yamanoi T., 2001. Reproductive performance and factors that decrease pregnancy rate in heavy draft horses bred at foal heat. J. Equine Vet. Sci. 21, 131-136, https://doi.org/10.1016/ S0737-0806(01)70109-8

Madil S., 2002. Reproductive considerations: mare and stallion. Vet. Clin. North Am. Equine Pract. 18, 591-619, https://doi. org/10.1016/S0749-0739(02)00030-5

Magee C., Foradori C.D., Bruemmer J.E., Arreguin-Arevalo J.A., McCue P.M., Handa R.J., Squires E.L., Clay C.M., 2009. Biological and anatomical evidence for kisspeptin regulation of the hypothalamic-pituitary-gonadal axis of estrous horse mares. Endocrinology 150, 2813-2821, https://doi. org/10.1210/en.2008-1698

Maliszewska M., 2011. Analysis of physiological, cytogenetic and organizational factors disturbing mares' reproduction (in Polish). PhD Thesis. Wrocław University of Environmental and Life Sciences, Wrockaw (Poland)

Marteniuk J.V., Carleton C.L., Lloyd J.W., Shea M.E., 1998. Association of sex of fetus, sire, month of conception, or year of foaling with duration of gestation in Standardbred mares. J. Am. Vet. Med. Assoc. 212, 1743-1745
McCue P.M., 2002. Equine Cushing's disease. Vet. Clin. North Am. Equine Pract. 18, 533-543, https://doi.org/10.1016/S07490739(02)00038-X

McCue P.M., Ferris R.A., 2012. Parturition, dystocia and foal survival: A retrospective study of 1047 births. Equine Vet. J. 44, 22-25, https://doi.org/10.1111/j.2042-3306.2011.00476.x

McCue P.M., Squires E.L., 2002. Persistent anovulatory follicles in the mare. Theriogenology 58, 541-543, https://doi.org/10.1016/ S0093-691X(02)00769-0

McDonnell S.M., 2000. Reproductive behavior of stallions and mares: comparison of free-running and domestic in-hand breeding. Anim. Reprod. Sci. 60-61, 211-219, https://doi.org/10.1016/ S0378-4320(00)00136-6

McKinnon A.O., Squires E.L., Vaala W.E., Varner D.D. (Editors), 2011. Equine Reproduction. 2nd Edition. Wiley-Blackwell, Hoboken, NJ (USA), pp. 1696-1753

Meyers P.J., Bonnett B.N., McKee S.L., 1991. Quantifying the occurrence of early embryonic mortality on three equine breeding farms. Can. Vet. J. 32, 665-672

Mills G., 2013. How far can we push the animals we use? Vet. Rec. 172, 518-519, https://doi.org/10.1136/vr. $\{3143$

Montovan S.M., Daels P.P., Rivier J., Hughes J.P., Stabenfeldt G.H., Lasley B.L., 1990. The effect of a potent $\mathrm{GnRH}$ agonist on gonadal and sexual activity in the horse. Theriogenology. 33, 1305-1321, https://doi.org/10.1016/0093-691X(90)90049-Y

Morris L.H.A., Allen W.R., 2002. Reproductive efficiency of intensively managed Thoroughbred mares in Newmarket. Equine Vet. J., 3451-3460, https://doi.org/10.2746/042516402776181222

Nowicka-Posluszna A., Zygmunt B., 2001. Evaluation of breeding indicators of mares used in Horse Studs in Pępowo, Posadowo and Racot in the years 1995-2000 including their pedigree model (part I) (in Polish). Rocz. Nauk. Zootech. Supl. 14, 309-317

Pycock J.F., 2006. How to maximize the chances of breeding successfully from the older maiden mare. Proc. Am. Assoc. Equine Pract. 52, 245-249

Robertson S.A., Sanchez L.C., 2010. Treatment of visceral pain in horses. Vet. Clin. North Am. Equine Pract. 26, 603-617, https://doi.org/10.1016/j.cveq.2010.08.002

Sairanen J., Katila T., Virtala A.-M., Ojala M., 2011. Effects of racing on equine fertility. Anim. Reprod. Sci. 124, 73-84, https://doi. org/10.1016/j.anireprosci.2011.02.010

Samper J.C. (Editor), 2009. Equine Breeding Management and Artificial Insemination. 2nd Edition. Saunders Elsevier. St. Louis, MO (USA), https://doi.org/10.1016/B978-1-4160-5234-0.X0001-3

Samper J.C., Pycock J.F., 2007. The normal uterus in estrus. In: J.C. Samper, J.F. Pycock, A. McKinnon (Editors). Current Therapy in Equine Reproduction. Saunders Elsevier. St. Louis, MO (USA), pp. 32-35, https://doi.org/10.1016/ B978-0-7216-0252-3.50009-6

Scoggin C.F., 2015. Not just a number: effect of age on fertility, pregnancy and offspring vigour in thoroughbred brood-mares. Reprod. Fertil. Dev. 27, 872-879, https://doi.org/10.1071/ RD14390

Sharma S., Davies Morel M.D., Dhaliwal G.S., 2010. Factors affecting the incidence of postpartum oestrus, ovarian activity and reproductive performance in Thoroughbred mares bred at foal heat under Indian subtropical conditions. Theriogenology, 74, 90-99, https://doi.org/10.1016/j.theriogenology.2010.01.018 
Stanton M.B., Steiner J.V., Pugh D.G., 2004. Endometrial cysts in the mare. J. Equine Vet. Sci. 24, 14-19, https://doi.org/10.1016/j. jevs.2003.12.003

Stout T.A.E., Colenbrander B., 2004. Suppressing reproductive activity in horses using $\mathrm{GnRH}$ vaccines, antagonists or agonists. Anim. Reprod. Sci. 82--83, 633-643, https://doi. org/10.1016/j.anireprosci.2004.04.009

van Niekerk C.H., van Heeden J.S., 1972. Nutrition and ovarian activity of mares early in the breeding season. J. S. Afr. Vet. Assoc. $43,351-360$
Vanderwall D.K., 2008. Early embryonic loss in the mare. J. Equine Vet. Sci. 28, 691-702, https://doi.org/10.1016/j.jevs.2008.10.001

Wilsher S., Allen W.R., 2003. The effects of maternal age and parity on placental and fetal development in the mare. Equine Vet. J. 35, 476-483, https://doi.org/10.2746/042516403775600550 